\title{
A new species and a new combination of Sundamomum (Zingiberaceae) from Sarawak, Borneo
}

\author{
Salasiah Mohamad ${ }^{1,2}$, Meekiong Kalu ${ }^{1} \&$ Axel Dalberg Poulsen ${ }^{3}$
}

Summary. A new ginger species, Sundamomum corrugatum from north east Sarawak is described. The species is easily recognised by its deeply corrugated leaves which at first glance might resemble Etlingera corrugata. The floral characters of the new species as well as of Amomum bungoense correspond well with the main characters circumscribing the genus Sundamomum, especially the anther crest, which is obscurely trilobed, but also by the coriaceous bract supporting a single flower, the pubescent inflorescence, the gullet-type labellum and their occurrence in the Sunda region. A detailed description and photographs of S. corrugatum are provided and the new combination of $S$. bungoense is made.

Key Words. Amomum, Alpinieae, diversity, ginger, Malesia, taxonomy.

\section{Introduction}

The pantropical ginger family (Zingiberaceae) produces aromatic oils and has vast economic value as spices, condiments, dyes, ornamentals, medicine, pharmaceuticals and cosmeceuticals. The family includes at least 53 genera and more than 1,500 species distributed in the tropics and subtropics, of which Southeast Asia hold the highest diversity and number of taxa (Lamb et al. 2013). Rosemary M. Smith published regional revisions on wild gingers in Borneo firstly focusing on Gunung Mulu National Park, Sarawak (Smith 1982, 1984) and later expanded to include the whole island $(1985,1986)$. Intensive studies were further conducted in 1998 - 2003 in Lambir Hills National Park by S. Sakai \& H. Nagamasu which eloquently reported 34 and 12 ginger species from the subfamilies Alpinioideae and Zingiberoideae respectively (Sakai \& Nagamasu 1998, 2001, 2003). Systematic studies of Zingiberaceae seem to be growing with the exploration of additional localities in Sarawak.

Despite several systematic papers on gingers of northern Sarawak, very few collections were made in the northeast area, which includes the Bintulu Division consisting of the districts of Bintulu and Tatau. Due to the alarming rate of land clearing and rapid deforestation in lowland Sarawak, it is imperative to document plant species of this region especially regarding highly localised species. Additionally, the high endemism and narrow distribution of Bornean gingers necessitate the study of their habitats, threats and conservation measures. Furthermore, Similajau National Park is the first totally protected area established in Bintulu District but so far no records were made on its ginger flora.

The previously accepted classification of the Zingiberaceae which was primarily based on morphological features, divided the family into four tribes namely Alpinieae A.Rich., Globbeae Meisn., Hedychieae Horan and Zingibereae Meisn. (Burtt \& Smith 1972). Subsequently, a new classification by Kress et al. (2002) based on DNA sequence data recognised four subfamilies and six tribes namely Siphonochiloideae W.J.Kress (tribe Siphonochileae W.J.Kress), Tamijioideae W.J.Kress (tribe Tamijieae W.J.Kress), Alpinioideae Link (tribe Alpinieae and tribe Riedelieae W.J.Kress), and Zingiberoideae Haask. (tribe Zingibereae and tribe Globbeae). The subfamily Alpinioideae is defined by the plane of distichy of the leaves being perpendicular to the rhizome and the reduction or absence of lateral staminodes. Alpinioideae is subdivided into two tribes i.e. Alpinieae and Riedelieae. The tribe Alpinieae is characterised by having fleshy or indehiscent fruits

\footnotetext{
Accepted for publication 26 April 2020.

1 Department of Plant Science and Environmental Ecology, Faculty of Resource Science and Technology, Universiti Malaysia Sarawak, 94300 , Kota Samarahan, Sarawak, Malaysia. e-mail: salasiah.mohamad@gmail.com

2 Department of Technology and Heritage, Faculty of Applied Science and Technology, Universiti Tun Hussein Onn Malaysia (Pagoh Campus), Pagoh Education Hub KM 1, Jalan Panchor, 84500, Pagoh, Johor, Malaysia.

3 Royal Botanic Garden Edinburgh, 20A Inverleith Row, Edinburgh, Scotland, EH3 5LR, UK.
} 